\title{
AWAL PERADABAN MASYARAKAT IBAN DI TEMBAWAI TAMPUN JUAH: SATU PENELITIAN AWAL
}

\author{
Gregory Kiyai@ Keai ${ }^{1, *}$
}

${ }^{1}$ Fakulti Seni Gunaan dan Kreatif, Universiti Malaysia Sarawak, 94300 Kota Samarahan, Sarawak, MALAYSIA.

\begin{abstract}
There are no clear sources explaining the origin of the Iban. However, through writings of the traditions inherited by several generations, it is believed that the existence of Iban started in a place known as Tembawai Tampun Juah, which was once regarded as a mighty civilisation situated in the district of Sanggau, West Kalimantan. It was found that once, the Iban lived together with Urang Panggau (Divine beings) and Petara (Gods) before conflict occurred, resulting in the separation between Gods and humans. The separation has caused the early Iban migration to every corner of the state of Sarawak. Therefore, they formed their own identity and downriver culture to be their main foundation. Therefore, this article is part of a series of an early study regarding the existence of the legendary settlement of the Iban in Tembawai Tampun Juah by referring to the perspective of written sources (collective memory), multiple relevant secondary references and early archaeological observation. The findings have discovered the location of Tembawai Tampun Juah as a permanent prehistorical site that is significant to the Iban. Although the site does not leave any artefacts or a definitive location every year during the Gawai Dayak celebration, Tembawai Tampun Juah situated on the far end of Kampung Segumon Kecamatan, Sekayam, Kalimantan receive visitors of Dayak Iban from various places all over Sarawak, Sabah, Brunei and Indonesia to celebrate and appreciate the history and lore at Tampun Juah.
\end{abstract}

Keywords: Origin; Dayak; Iban; Tembawai Tampun Juah; Sarawak

* Corresponding author: gregory_kiyai@yahoo.com eISSN: 2636-9257 CPusat Dialog Peradaban Universiti Malaya, 2021

DOI: https://doi.org/10.22452/PERADABAN.vol14no1.3 


\begin{abstract}
Abstrak
Tiada sumber yang jelas darimana asal usul masyarakat Iban, akan tetapi melalui tradisi lisan yang diwariskan serta diturunkan selama beberapa generasi mempercayai bahawa kewujudan dan asal usul masyarakat Iban adalah bermula di sebuah tempat yang disebut sebagai Tembawai Tampun Juah iaitu peradaban Dayak yang gah terletak di daerah Sanggau, Kalimantan Barat. Mereka meyakini bahawa nenek moyang mereka dahulu pernah hidup aman dan damai bersama dengan Urang Panggau (orang kayangan) dan Petara (tuhan) sebelum berlakunya konflik yang akhirnya menyebabkan manusia berpisah dengan tuhan. Perpisahan tersebut telah menyaksikan migrasi awal masyarakat Iban ke seluruh pelusuk negeri Sarawak lalu membentuk kebudayaan dan identiti tersendiri. Oleh itu, artikel ini merupakan satu penelitian awal mengenai kewujudan penempatan sebuah ketamadunan masyarakat Iban di Tembawai Tampun Juah berdasarkan kepada perspektif sumber lisan (Collective Memory), beberapa bahan rujukan skunder yang relevan dan pemerhatian awal arkeologi. Berdasarkan kepada data mendapati bahawa kawasan Tembawai Tampun Juah menjadi legenda yang kekal signifikan dalam budaya masyarakat Iban. Walaupun, tidak meninggalkan artifak atau tapak secara zahirnya, namun saban tahun menjelang perayaan Gawai Dayak, Tembawai Tampun Juah yang terletak di hulu Kampung Segumon Kecamatan, Sekayam, Kalimantan menerima kunjungan masyarakat Dayak Iban yang pelbagai dari seluruh penjuru Sarawak, Sabah, Brunei dan Indonesia untuk meraikan dan menghayati sejarah dan cerita di Tembawai Tampun Juah.
\end{abstract}

Kata Kunci: Asal Usul; Dayak; Iban; Tembawai Tampun Juah; Sarawak

\title{
Pengenalan
}

Negeri Sarawak Bumi Kenyalang merupakan sebuah negeri yang terletak di barat laut Pulau Borneo dan menghadap ke Laut China Selatan. Dengan keluasan 124,450 kilometer persegi, Sarawak adalah negeri terbesar di Malaysia. Permukaan bumi Sarawak meliputi Kira- kira 48,000 batu persegi dengan pantainya kira- kira 500 batu panjang. Bentuk muka bumi Sarawak terdiri daripada kawasan pergunungan di tenggara dan tanah pamah di barat laut. Kawasan sempadannya dengan Kalimantan mempunyai ketinggian di antara 2500 hingga 4000 kaki dari paras laut (Ismail \& Mohd Noor, A, 2019). Kini, Iban atau dirumpunkan sebagai Sea Dayak dikenali sebagai etnik terbesar mendiami negeri Sarawak dengan populasi sebanyak 2,471,140 orang dan dari jumlah ini, majoriti penduduknya mendiami kawasan di Sri Aman, Betong, Bintulu, Miri, Samarahan, Kapit, Limbang, Lubok Antu dan Sibu (Population Distribution and Basic Demographic Characteristics, 2010). Suatu ketika, Malaysia dan Indonesia pernah mempunyai sejarah yang tegang disebabkan oleh isu politik dan juga persamaan budaya disebabkan oleh keserumpunan dari cara hidup dan kebudayaan. Oleh itu, kewujudan Tembawai Tampun Juah sememangnya memberi nilai yang signifikan kepada dua negara untuk bersatu dan berdiri sebagai satu rumpun di Nusantara. 


\section{Masyarakat Iban Sarawak}

Menurut Bellwood (2004) masyarakat yang menetap di Asia Tenggara kini adalah sebagai kelompok Austronesia yang berhijrah dari selatan Yunan, Taiwan sekitar tahun 3,500 SM sehingga $3000 \mathrm{SM}$. Dia percaya bahawa kumpulan ini telah menyebarluas dari Filipina ke Borneo dan Sulawesi sekitar tahun 3000 SM sehingga 2500 SM. Teori Bellwood ini adalah berdasarkan kepada penelitiannya terhadap aktiviti penanaman sekoi, penjinakan anjing dan juga pengembumian menggunakan Jed Taiwan yang dilihat menyerupai budaya di Yunan. Masyarakat Iban di Sarawak telah dikelompokan sebagai kumpulan Austronesia bersama-sama dengan kumpulan etnik lain di Asia Tenggara. Walaubagaimana pun, pengaruh China dalam kebudayaan Iban adalah sangat rendah dan tidak menonjol berbanding dengan kumpulan masyarakat di Indochina. Bentuk kebudayaan masyarakat Iban adalah sangat mirip dengan kebudayaan yang diamalkan oleh bangsa Melayu di Semenanjung Malaysia dan penduduk peribumi di Indonesia seperti di Sumatera dan Kalimantan.

Kekusutan mengenai asal usul masyarakat Iban telah berjaya menemui satu titik penemuan awal melalui penyelidikan genetik Simonson, et.al (2011) mengatakan migrasi awal manusia melintasi laluan darat Sundaland yang menghubungkan daratan Asia Tenggara telah berlaku kira-kira 45,000 SM sehingga 50,000 SM yang lalu. Bukti persampelan genetik mencadangkan bahawa teori yang mengatakan bahawa masyarakat Austronesia berasal dari selatan Taiwan adalah sangat rendah. Penyelidikan terbaru menunjukkan berdasarkan kepada analisis DNA telah menyimpulkan bahawa migrasi dari daratan Asia Tengara berlaku dalam jajaran yang sama. Diramalkan bahawa beberapa garis keturunan yang dikaitkan dengan migrasi prasejarah zaman ais batu terakhir telah mewujudkan satu gelombang penghijrahan iaitu melalui garisan pantai SEA (South East Asia). Masyarakat Iban dipercayai antara yang terlibat dalam migrasi awal tersebut berdasarkan kepada penemuan fosil manusia primitif yang telah digali berdekatan dengan penempatan moden rumah panjang Masyarakat di Gua Niah menyakini bahawa masyarakat Iban telah wujud sekitar period tersebut.

Perkara ini pernah dijelaskan oleh Stephen Oppenheimer (1998) melalui teorinya bahawa sebelum Zaman Glasier Batu Ais, sebahagian daripada tanah besar Asia Tenggara telah bercantum dengan Pulau Jawa dan Sumatera membentuk Benua Sunda yang besar. Period tersebut telah menyaksikan kepelbagaian ciri-ciri genetik yang tiba 70,000 SM lalu masih terdapat di rantau Sunda, di Barat Daya dan Asia Tenggara. Menurutnya lagi, telah berlakunya banjir besar sekitar 14,000 SM sehingga 8000 SM tahun lampau akibat daripada pencairan ais telah menyebabkan paras laut meningkat. Perkara ini telah memaksa masyarakat yang tinggal di kawasan pesisir dan di tanah rendah berpindah bagi mencari kawasan yang lebih tinggi. Perpindahan tersebut telah menyebabkan percampuran sosial dalam masyarakat primitif lalu membangunakan kebudayaan bersama. 
Beberapa orang sarjana seperti Koenjaraningrat (1987) mengatakan bahawa AustroMalanesoid iaitu rumpun penutur Austronesia sememangnya sudah lama tersebar ke timur dan barat Pulau Jawa sehingga ke Sumatera, Semenanjung Tanah Melayu, selatan Thailand dan utara Vietnam. Bahkan, penyelidikan Stephen Oppenheimer (1998) mengatakan bangsa yang wujud di Asia Tenggara pada masa kini adalah hasil evolusi Orang Asli yang merupakan kumpulan peneroka terawal masyarakat dan telah berevolusi selama 50,000 SM. Kumpulan ini telah berpecah kepada beberapa etnik disebabkan oleh migrasi dan juga konflik, antaranya adalah kaum Jahai, Temiar dan Mendrik yang mana kemudiannya berpecah lagi kepada keluarga yang lebih besar seperti Jakun, Kanaq, Seletar dan Dayak. Menurut Asmah Omar (1985) kumpulan ini telah dikenalpasti sebagai Melayu Proto, dimana ia pada akhirnya telah membangun kepada ras Melayu moden seperti Iban, Jawa, Temuan, Biduanda, dan Minang.

Selain itu, Hamid Darmadi (2017) mengatakan etnik Dayak merupakan penduduk asal dan etnik tertua yang menetap di Pulau Borneo terutamanya di Kalimantan. Istilah 'Dayak" telah digunakan oleh penjajah Belanda dan Inggeris pada pertengahan abad Ke-18 dan awal abad Ke-19 bagi mengklasfikasikan masyarakat peribumi di Sarawak dan Kalimantan yang mengamalkan cara hidup yang masih tradisional dan berbeza dengan etnik-etnik peribumi Islam seperti Melayu dan Banjar. Dari penelitian ketamadunan, suatu ketika dahulu suku Dayak dipercayai pernah membangun sebuah kerajaan iaitu Dayak Nansarunai atau disebut Nansarunai Usak Jawa. namun telah musnah akibat diserang oleh kerajaan Majapahit yang merupakan satu kerajaan besar seangkatan dengan kerajaan Srivijaya pada tahun 1309 sehingga 1389. Kejadian itu telah menyebabkan suku kaum Dayak berpecah dan melarikan diri ke kawasan pendalaman dan mendiami segenap pelosok wilayah Indonesia, Sabah, dan Sarawak. Sebahagian besar etnik Dayak yang telah memeluk agama Islam ketika itu, tidak menyebut mereka sebagai Dayak tetapi mengantikannya dengan nama Melayu atau urang Banjar, sedangkan Dayak yang masih kuat menganuti agama nenek moyang telah terisolasi menyelusuri hulu sungai, kawasan pendalaman Sarawak dan Kalimantan lalu membangunkan budayanya sendiri sebagai identiti mereka hari ini, termasuklah kaum Iban di Sarawak.

Sejarah awal kewujudan masyarakat Iban tidak meninggalkan bukti yang jelas dan nyata dari mana asal-usulnya. Walaubagaimanapun, masyarakat Iban sudah mengidentifikasikan diri mereka sebagai Iban sejak dahulu lagi, sebelum bangsa Kayan mengelarkan mereka sebagai $H i$ van yang bermaksud pengembara. Hal ini telah dijelaskan oleh Bennedict Sandin (1962) bahawa perkataan "Iban" adalah merujuk kepada mensia (manusia) dalam Bahasa Iban. Menurut Pringle (1936) berdasarkan gambaran cerita legenda Orang Tau Tusut (Pakar Susurgalur), migrasi orang Iban dipercayai bermula sejak enambelas generasi yang lepas, iaitu kira- kira pada pertengahan kurun ke-16 iaitu dari Hulu Kapuas, Indonesia ke Batang Lupar. Dari Batang Lupar, mereka telah menyebar luas ke sekitar sungai-sungai yang berdekatan seperti Sungai Saribas, Batang Ai, dan Batang Rejang. Penempatan tersebut 
telah kekal menjadi penempatan masyarakat Iban moden pada hari ini. Menurut Neilson Ilan Mersat (2012) dispora masyarakat Iban dari Kapuas Hulu, Indonesia ke Sarawak adalah bermula dari tahun 1526 iaitu 500 sehingga 600 tahun yang lepas. Migrasi tersebut telah berlaku secara berperingkat iaitu melalui dari Hulu Kapuas telah menyelusuri ke Batang Lupar dan memasuki bahagian Undop di Sri Aman, setelah itu menyelusuri ke Sungai Saribas dan Sungai Skrang sehinggalah ke Batang Ai di Lubok Antu. Peringkat kedua adalah, apabila masyarakat Iban telah melakukan migrasi ke Batang Rejang sehinggalah ke bahagian Limbang.

\section{Diaspora Masyarakat Iban}

Dispora masyarakat Iban pada masa dahulu adalah dipengaruhi oleh adat bejalai (mengembara) dan Ngayau (memburu kepala) yang telah mendorong setiap pemimpin Iban berperang untuk menerokai kawasan baharu (Kedit, 1993). Masyarakat Iban amat menyanjung tinggi budaya bejalai kerana dikaitkan dengan dengan elemen kepercayaan spiritual, nilai sosial dan mitologi, iaitu sesorang lelaki Iban yang bejalai akan membawa rohnya bersama-sama menempuhi alam spiritual tersebut. Selain itu, budaya bejalai adalah kerana terlibat dalam kegiatan perdagangan seperti mencari tajau (tembikar) yang dapat mengangkat martabat sosial sehingga mereka sanggup bejalai dari wilayah sosial mereka (Baginda \& Bala, 2018). Dahulu, tajau adalah merupakan sebuah objek budaya yang sangat bernilai dalam status sosial masyarakat Iban, setiap keluarga yang memiliki tajau yang banyak akan dipandang sebagai keluarga bangsawan dalam rumah panjang. Objek tajau turut berfungsi sebagai matawang dan digunakan sebagai hantaran dalam perkahwinan tradisional Iban (Kiyai \& Tugang, 2020).

Masyarakat Iban tidak hanya mengembara di daratan, bahkan turut menguasai lautan. British telah mengelarkan Iban sebagai Sea Dayak. Menurut Azian Tahir \& Arba'iyah (2017) berdasarkan kepada laporan British The Illustrated London News 1845 sehingga 1872 mendefinisikan bahawa Dayak Laut (yakini masyarakat Iban kini) dikenali sebagai pahlawan dan pemburu kepala yang sering bersekutu dengan pelanun Melayu. Mereka membunuh dan menyerang dalam usaha menawan sebuah kapal yang disyaki membawa emas, perak dan barangan berharga lain. Modus operandi mereka adalah membunuh dan mencederakan semua anak kapal dan penumpangnya sekiranya kehendak mereka tidak dituruti. Kumplan inilah yang hebat menentang dan ditentang oleh Sepanyol, Belanda dan British. Pada abad Ke-19, British telah menyerang balas kawasan lanun Sulu seperti di sekitar laut sekeliling Austronesia berhampiran dengan kawasan penduduk Polynesia. Dalam pemburuan lanun di Borneo, pihak British telah berusaha untuk menghapuskan acaman lanun untuk menjaga kepentingan perdagangan mereka.

Menurut Pringle (1936) sebelum kemasukan penjajah ke Sarawak, masyarakat Iban tidak mempunyai terma yang spesifik untuk mengidentifikasi diri sendiri seperti masyarakat Iban kini. Walaubagaimanapun, mereka akan mengklasfikasi pengenalan diri berdasarkan kepada sungai yang menjadi penempatan mereka. Contohnya We of 
Skrang (kami skrang) atau We of Undop (kami Undup) bahkan mereka akan merujuk kepada We of this area (Kami Menua). Kaedah identifikasi tersebut telah menjadi budaya dalam pengkelasan masyarakat Iban di Sarawak. Kini, Dayak yang berbahasa Ibanic dapat dirumpunkan kepada dua kategori, pertama Ibanic yang menetap di Sarawak, Malaysia iaitu Balau, Remun, Sebuyau, Lemanak, Skrang, Undup, Saribas dan Ulu Ai. Kedua adalah merujuk kepada Ibanic di Kalimantan Barat dan Timur, Indonesia iaitu Mualang, Seberuang, Bugau, Kantu, Desa, Sebaruk dan Banyur (Damianus \& Yankris, 2014).

\section{Metodologi Penyelidikan Kumpulan informan}

Kaedah penyelidikan kajian ini adalah berbentuk kualitatif dan pengumpulan yang digunakan untuk mendapatkan data adalah menggunakan teknik Collective Memory iaitu temubual secara individu (in-depth interview). Menurut Mead's (1929) Collective Memory adalah satu ingatan kolektif yang pada dasarnya merupakan penyusunan semula masa lalu dan menyesuaikan imej, kepercayaan, dan pengalaman tersebut dalam masa kini. Informan yang ditemubual merupakan pakar dalam susur galur cerita lisan dan mempunyai pengalaman luas dalam budaya masyarakat Iban di Sarawak dalam mendapatkan maklumat dan gambaran sejarah di Tampun Juah. Kumpulan informan adalah terdiri daripada:

i. Encik Tugang Rima (76 tahun) tetua Iban yang memiliki kepakaran dalam sejarah dan budaya masyarakat Iban

ii. Puan Janet Rata Noel (50 tahun), Kurator Tun Jugah Foundation

iii. Datuk Sri Edmmund Langgu ak Saga, Tokoh Politik dan Pakar Budaya Iban

iv. Encik Jimbun Tawai (65 tahun) Penyelidik Majlis Adat Istiadat Sarawak

v. Bapak Agus Mulyana (47) penyelidik Institut Dayakologi, Pontianak, Indonesia

vi. Lemambang (pendeta) Abang Enterey ( 85 tahun) pengamal kebudayaan Iban

vii. Lemambang (pendeta) Kudi (75 tahun) pengamal kebudayaan Iban

viii. Lemambang (pendeta) Buchaw Undan (90 tahun) pengamal kebudayaan Iban

\section{Kaedah pengumpulan data}

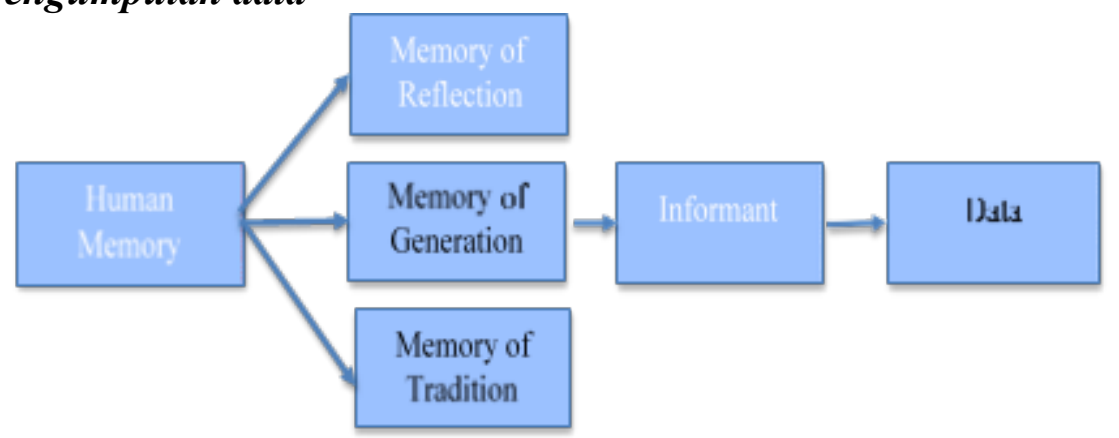

Rajah 1: Collective Memory 
Pengumpulan data telah dilakukan berdasarkan kepada pengumpulan cebisan-cebisan memori informan. Collective Memory adalah satu tindakan yang memasukan faktor representasi kolektif (simbol, makna, naratif, dan ritual yang sedia ada dalam sesebuah masyarakat), struktur budaya, dan kenangan individu yang secara peribadi dan terbentuk oleh sosial budaya (Olick, 1999: Kiyai, 2021). Memori informan yang telah dipilih adalah dinilai kepada tiga kategori berdasarkan kepada rajah diatas. Pertama adalah memory of reflection adalah merupakan ingatan peribadi seseorang yang melibatkan interaksi dengan orang-orang disekitarnya sehingga sulit untuk dilupakan oleh orang yang mengalami peristiwa tersebut. Kedua, memory of generation adalah memori yang diturunkan oleh suatu generasi yang lebih tua kepada generasi penerusnya atau generasi yang lebih muda sehingga memori tersebut terus hidup dalam budaya dan ketiga adalah memory of tradition adalah satu ingatan yang statik, berorentasi pada masa lalu dan bersifat konservatif.

Selain itu, ingatan tersebut adalah tahan terhadap perubahan dan sebagai alat untuk mengintergrasikan di antara masa lalu dan masa kini sehingga wujud perkembangan yang seimbang. Selain itu, penyelidikan ini turut meneliti dan mengkaji sumber sejarah yang berlaku di Kepulauan Borneo untuk mentafsir masa silam yang relevan dengan kewujudan Tembawai Tampun Juah berdasarkan kepada penulisan-penulisan sarjana lepas serta memahami kehidupan manusia awal di Kepulauan Borneo dengan merujuk kepada dapatan arkeologi yang telah dijalankan oleh sarjana lepas.

\section{Lokasi Penyelidikan}

Lokasi penyelidikan adalah dilakukan di beberapa tempat di Sarawak iaitu di Kuching, beberapa buah rumah panjang Rumah panjang Assan Semena, Nanga Medamit, Limbang, Rumah panjang Ribun, Tinting Melaban, Sungai Kelampai, Saratok dan Rumah panjang Kunjang Entawa Asal, Sri Aman. Selain itu, penyelidikan ini turut melibatkan Tun Jugah Foundation dan Majlis Adat Istiadat Sarawak serta Institut Dayakologi, Pontianak, Indonesia.

\section{Dapatan Penyelidikan}

Penempatan masyarakat Iban moden kini adalah tertumpu di kawasan pedalaman dan hidup secara berkomuniti di rumah panjang. Umumnya, mereka masih meneruskan cara hidup nenek moyang walaupun sebahagian besar daripada mereka telah memeluk agama baharu iaitu agama Kristian. Berdasarkan informan Datuk Seri Edmmund Langgu dalam kelompok Ibanik itu sendiri, kumpulan ini cenderung untuk mengidentifikasi sesama mereka berdasarkan kepada penempatan atau sungai-sungai yang didiami oleh mereka. Identifikasi tersebut dapat dilihat kepada beberapa pecahan sungai di Sarawak seperti pada Rajah 2 iaitu: 


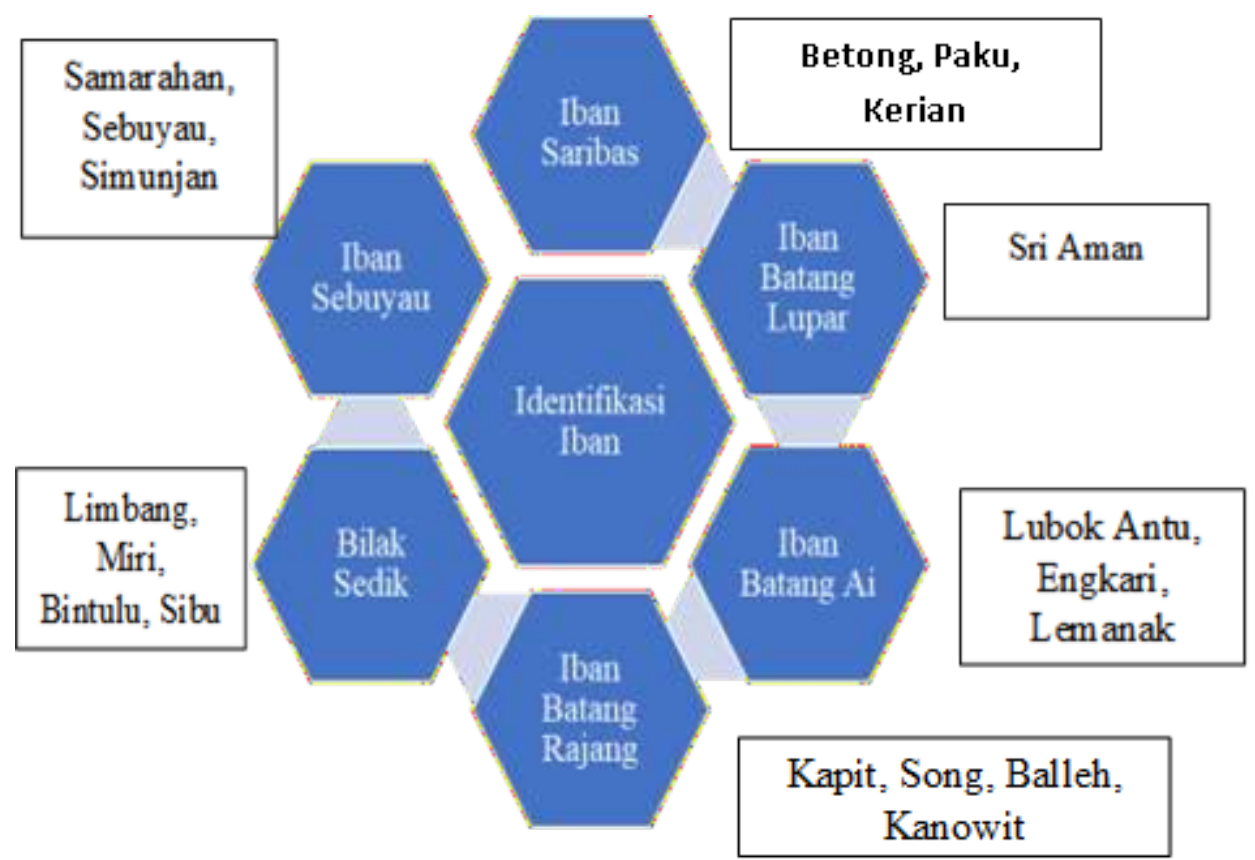

Rajah 2: Identifikasi Iban di Sarawak. (Diubahsuai dari temubual dengan Datuk Sri Edmmund Langgu, 2019)

Selain itu, pengenalpastian identifikasi ras etnik Iban di Sarawak dapat dikenalpasti melalui beberapa aspek iaitu bahasa dan busana. Menurut informan Tugang Rima, terdapat perbezaan makna dan intonasi komunikasi di antara masyarakat Iban yang tinggal di Bahagian Sungai Rejang dan Batang Ai dengan masyarakat Iban yang menetap di Sungai Saribas. Intonasi suara masyarakat Iban Sungai Rejang (merujuk Kapit, Sibu, Kanowit dan Batang Ai) adalah lebih kasar dan keras berbanding dengan masyarakat Iban yang menetap di Sungai Saribas yang lembut dan perlahan rimanya. Faktor ini adalah kerana wujudnya wong ai (pusaran air besar) yang kuat sehingga mengeluarkan bunyi bising di Sungai Rejang menyebabkan masyarakat setempat harus menggunakan nada suara yang keras dan tinggi dalam berkomunikasi antara satu sama lain.

Informan Janet Rata Noel, kurator Tun Jugah Foundation mengatakan busana atau dikenali sebagai Ngepan merupakan identiti masyarakat Iban di Sarawak, walaubagaimanapun wujud beberapa ciri khas dan perbezaan dalam setiap busana tradisional ini. Dalam budaya Iban telah dikenalpasti beberapa jenis Ngepan Iban iaitu Ngepan Saribas (Betong, Paku, Krian), Ngepan Kuas (Undop, Sri Aman, Lingga), Ngepan Dunjung Marik (Kapit), Ngepan Batang Ai (Lubuk Antu, Lemanak, Engkelili) dan Ngepan Iban biasa (digunakan oleh semua Iban). Pengenalpastian ini adalah berdasarkan kepada kawasan penempatan atau nama-nama sungai yang berdekatan dengan masyarakat Iban di Sarawak. Wujudnya perbezaan dalam kalangan masyarakat Iban adalah dipengaruhi oleh faktor migrasi dan adaptasi budaya. 


\section{Tembawai Tampun Juah}

Lagenda Tembawai Tampun Juah atau Tembawang Tampun Juah adalah merujuk kepada sebuah penempatan awal yang menjadi sebuah legenda bagi penempatan leluhur nenek moyang mereka. Dalam kesusasteraan Iban, Tampun Juah adalah merupakan tanah yang suci bagi kumpulan Ibanik di Sarawak dan Kalimantan. Berdasarkan penceritaan lisan informan Datuk Sri Edmmund Langgu, setelah berpisah dengan Petara (tuhan) dan Urang Panggau (orang kayangan) beratus-ratus tahun yang lalu. Masyarakat Dayak dari rumpun Ibanik sejak dari itu berusaha untuk mencari semula penempatan lagenda nenek moyang mereka iaitu Tembawai Tampun Juah. Walaubagaimanapun, kisah penemuan semula tapak Tembawai Tampun Juah adalah berawal dari mimpi penduduk tempatan di Kampung Dusun Segumon sekitar tahun 1940-an iaitu semasa menerokai kawasan di hutan Segumon untuk mendirikan penempatan. Kisah penemuan tapak Tembawai Tampun Juah adalah bermula apabila penduduk tempatan terdahulu ingin membuka kawasan penempatan di hutan tersebut. Sepanjang proses pembersihan hutan di kawasan Segumon, pelbagai pekara pelik yang telah berlaku sehingga menggangu kerja-kerja pembersihan di kawasan tersebut. Sehingga pada suatu malam salah seorang penduduk tersebut bermimpi bertemu dengan Urang Panggau yang meninggalkan pesan menyatakan bahawa kawasan tersebut adalah tapak legenda yang dicari oleh masyarakat Iban sejak dahulu lagi.

Walaupun terdapat pelbagai pandangan sarjana mengenai asal-usul dan migrasi masyarakat Iban, namun masyarakat Iban tradisional menyakini bahawa penempatan awal rumpun Ibanik adalah bermula di Tembawai Tampun Juah. Kehebatan dan keagungan Tembawai Tampun Juah diceritakan secara turun temurun dalam tradisi lisan masyarakat Iban dalam bentuk puisi, cerita rakyat dan pantun. Menurut informan Jimbun Tawai, lokasi kawasan Tembawai Tampun Juah adalah terletak di hulu Kampung Segumon Kecamatan, Sekayam iaitu kira-kira satu jam perjalanan daripada bandar Sekayam Balai Karangan di daerah Sanggau, Kalimantan Barat berdekatan dengan persempadanan Malaysia- Indonesia iaitu di Pekan Serian. Kawasan seluas 651 hektar di Tembawai Tampun Juah sejak tahun 2018 telah diwartakan sebagai hutan adat oleh kerajaan Indonesia melalui Kementerian Lingkungan Hidup dan Kehutanan. Ini adalah sebagai langkah untuk membudayakan kebudayaan ketara dan tidak ketara bagi masyarakat setempat dalam perlindungan sumber hutan, kearifan tradisi dan cara hidup masyarakatnya. Apa yang menarik, kerajaan Indonesia telah memberikan kuasa kepada masyarakat setempat dalam menguruskan kawasan hutan di Tembawai Tampun Juah berdasarkan kepada kebudayaan nenek moyang mereka dalam melindungi tanah adat dan tanah leluhur mereka. Pengurusan tersebut mencakupi hukum adat dalam penjagaan hutan, hub serantau bagi kumpulan Ibanik dalam merayakan hari Gawai Dayak serta usaha untuk melestarikan hutan melalui kearifan tradisi. 


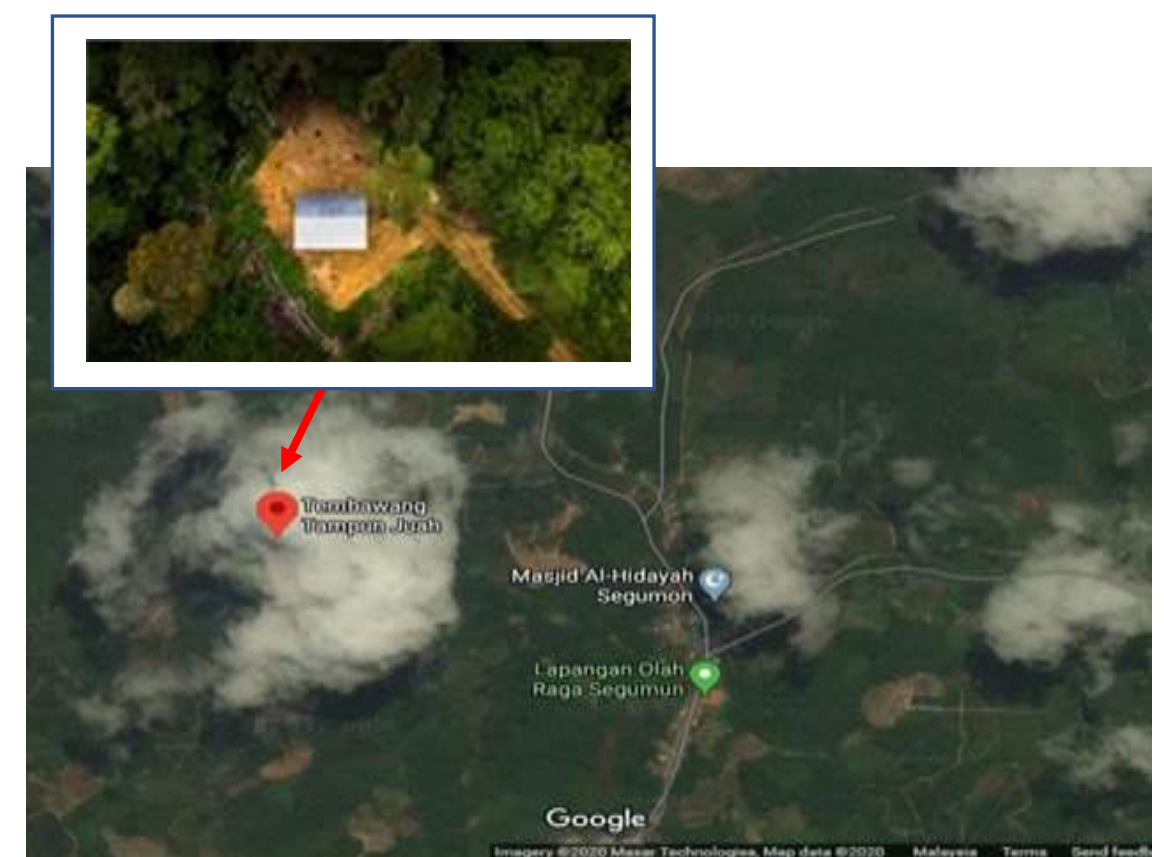

Rajah 3: Peta Tembawai Tampun Juah (Gambar: Google Maps, 2020 dan Jefferson Neo Nuing, 2019)

Menurut informan Jimbun Tawai, Tembawai Tampun Juah adalah tempat leluhur asal masyarakat Iban berdasarkan kepada budaya leka main (tradisi lisan) iaitu berjudul Mengap Bungai Taun. Dalam puisi tersebut ada menyebut tentang beberapa orang tokoh pahlawan Iban yang mempunyai kuasa sakti seperti Laja, Keling, Ijau, Pandung dan Pungga. Puisi ini turut menyebut beberapa orang perempuan yang sehingga kini dijadikan ikon dalam budaya Iban seperti Kumang, Lulong dan Indai Abang. Kesusasteraan leka main ini dicipta bagi menyatakan rasa kerinduan mereka terhadap Tembawai Tampun Juah selepas berpisah dengan Urang Panggau. Dahulukala, berdasarkan kepada temubual bersama-sama Alloy Sujarni (2008) mengatakan Tembawai Tampun Juah merupakan penempatan legenda bagi rumpun Ibanik di Borneo, kisah ini telah diceritakan secara turun temurun dalam tradisi lisan masyarakat Iban. Mereka percaya bahawa suatu ketika dahulu masyarakat Iban yang dikenali sebagai Mensia pernah hidup dekat bersama-sama dengan Petara kira-kira 2000 tahun dahulu. Kedekatan masyarakat Iban dengan Petara diibaratkan senipis kulit terung dan tetua Iban menggambarkan melalui kolektif memori bahawa masyarakat Iban dapat melihat dan berkomunikasi langsung dengan roh iaitu Urang Panggau, Sebayan (roh orang Iban yang telah mati), dan Antu (semengat). Penempatan mereka ini diibaratkan tinggal di sebuah sungai yang panjang dan tidak berpenghujung iaitu Urang Panggau (orang kayangan yang merujuk kepada dewadewi Iban) tinggal di hulu sungai, manakala Urang Mensia (Iban) tinggal ditengah sungai dan Sebayan (roh orang yang sudah meninggal) tinggal di hilir sungai yang tidak berpenghujung.

Mengikut informan Agus Mulyana, penyelidik Institut Dayakologi di Pontianak, Indonesia berdasarkan kepada cerita dari masyarakat Iban di Kapuas Hulu 
mengatakan bahawa asal usul nama Tembawai Tampun Juah adalah diambil dari kisah lelaki yang bernama Juah dan perempuan Lemay yang telah Jadi Mali (kahwin sedarah). Dalam budaya Iban, perkahwinan yang mempunyai hubungan kekeluargaan yang sangat dekat adalah sangat bertentangan dengan norma masyarakat Iban. Sekiranya di dapati bersalah, maka mereka harus dihukum dengan cara rejam sampai mati menggunakan buluh dan mayatnya akan dihanyutkan di sungai bagi membersihkan tahah leluhur dari dosa dan bencana. Oleh itu, makna Tampun adalah bermaksud hukum "Hukuman kepada Juah" sehingga membawa kepada "Tampun Juah".

Berdasarkan kepada temubual bersama Lemambang (pendeta) Abang Enterey mengatakan penempatan awal di Tembawai Tampun Juah menurut legenda adalah bermula dengan 30 buah rumah panjang dan kemudianya berkembang pesat sehingga menjadi lebih 100 buah rumah panjang. Hal ini disebabkan tanah yang terdapat di Tembawai Tampun Juah dikatakan cukup subur sehingga apa sahaja yang ditanam akan menjadi, malahan sungai serta hutannya tidak pernah kering apabila musim kemarau dan sentiasa memberikan rezeki yang melimpah untuk penduduknya bagi meneruskan aktiviti kehidupan. Perkara ini turut dinyatakan oleh Drake Allen Richard (penyelidik Institusi Dayakologi, Kalimantan Barat) dalam sejarah lisan Dayak Mualang, semasa zaman kegemilangan di Tembawai Tampun Juah peradaban masyarakat Dayak sangat maju dan berkembang dengan baik sehingga menjadi kuasa yang kuat di Pulau Borneo sehingga kekuatan mereka dilihat sebagai sebuah ancaman oleh kerajaan Sukadana.

\section{Kemunculan Kerajaan Tampun Juah}

Terdapat beberapa buah kerajaan kuno di Borneo yang telah dikenalpasti berkemungkinan memiliki hubungan budaya dan pengaruh dengan masyarakat Iban kini. Melalui kajian arkeologi, salah satu sungai besar yang sering dinyatakan oleh lagenda tempatan adalah Sungai Mahakam yang mengalir di Kalimantan Timur. Salah satu cabang anak sungai yang terletak di Muara Kaman dipercayai merupakan penempatan tamadun awal di Borneo iaitu kerajaan Kutai Martadipura. Sumber sejarah Kutai sebelum kerajaan tersebut memeluk agama Islam pada abad Ke-14 tidak meninggalkan jejak yang nyata dan hanya bergantung dengan sumber lisan penduduk setempat. Namun pada tahun 1879 telah dijumpai sebuah Prasasti Yupa (batu bersurat) di Bukit Berubus di Muara Kaman, Kalimantan Timur. Tulisan batu tersebut telah ditulis menggunakan sistem tulisan Pallava dalam Bahasa Sanskrit, yang mana tulisan ini telah digunakan secara meluas di India oleh para Brahman. Berdasarkan kepada tulisan batu tersebut mengatakan bahawa pengasas kepada kerajaan kuno Kutai tersebut adalah merupakan seorang pembesar dari Champa yang bernama $G a$ - Dong- $G a$ atau Kudungga. Namun, pernyataan ini telah dibidas oleh para sejarahwan bahawa Kudungga adalah merupakan penduduk asli di Pulau Borneo dan bukan imigran dari Champa atau India (Muhammad Sarip, 2020).

Melalui tarikh prasasti yupa tersebut telah menjangkakan banyak teori mengenai 
kewujudan awal kerajaan ini termasuklah ahli epigrafi, Louis Charles Damais telah menetapkan ianya muncul pada sekitar tahun 425 Masehi dan Edhie Wurjantoro, ahli arkeologi Indonesia telah mentafsirkan bahawa kerajaan ini wujud pada pertengahan abad Ke-5 iaitu sekitar tahun 450 Masehi (Sanib Said, 2012: Muhammad Sarip, 2020). Oleh itu, tiada tarikh yang jelas akan kewujudan kerajaan Kutai pada umumnya. Namun sejarahwan bersetuju bahawa kerajaan ini wujud sekitar abad Ke-4 dan Ke-5 Masehi. Selepas berakhirnya pemerintahan Raja Kudungga, maka pemerintahan Kutai diambil alih oleh Aswawarman iaitu anaknya. Semasa era pemerintahan beliau, masyarakatnya telah menganuti ajaran Hindu Buddha disebabkan oleh faktor perdagangan yang baik dengan kerajaan India dan China serta memiliki hubungan diplomasi dengan kerajaan luar seperti Kerajaan Champa di Vietnam. Kerajaan Kutai mencapai masa kegemilangannnya semasa dibawah pemerintahan Mulawarman (cucu Kudungga). Ruang jajahan kerajaan Kutai Kuno menyebar sehingga ke Sarawak. Kejatuhan Kerajaan Kutai adalah dianggarkan terjadi apabila tewasnya Maharaja Dhrama Setia ke atas tangan Raja Kutai Kartanegara iaitu sebuah kerajaan pra Islam di bawah permerintahan Aji Pangeran Anum Panji Mendap pada abad Ke-13. Peperangan tersebut dikatakan berlaku selama tujuh hari tujuh malam. Kesan daripada kekalahan tersebut telah menyebabkan kerajaan Kutai menjadi sebuah kerajaan Islam dan menukar namanya kepada Kutai Kartanegara Marthadipura (Sofwan Noerwidi, 2010).

Kesan dari kekalahan itu, telah mengakibatkan masyarakat Dayak Mulang bersamasama Dayak lainnya dari kerajaan Sekadau (sebuah kerajaan kecil di Kutai) bermigrasi ke luar untuk mencari Tampun Juah yang dipercayai sebagai tanah yang suci kerana menolak kemasukan agama Islam. Rombongan tersebut yang dipimpin oleh Patih Bardat dan Patih Bangi telah menyelusuri Sungai Sekayam yang terletak di Sanggau, Kalimantan Barat. Dalam perjalanan menyelusuri Sungai Sekayam, mereka telah berjumpa dengan puteri dari kerajaan Sukadana iaitu Dara Nante bersama-sama rombongannya untuk mencari suaminya iaitu Babai Cinga yang hilang. Pertemuan tersebut telah membawa kesepakatan antara kedua-dua rombongan tersebut untuk mengharungi Sungai Sekayam bersama-sama dan akhirnya menemui tanah Tampun Juah yang terletak di hulu Sungai Entabai. Berkat dari kerjasama tersebut telah menyebabkan Dara Nenta bertemu semula dengan suaminya iaitu Babai Cinga. Menurut cerita, Tembawai Tampun Juah merupakan tempat persinggahan dan pusat berkumpulnya suku- suku Dayak dari pelbagai etnik yang bermigrasi dari penjuru Borneo (Lontaan, 1975).

Menurut Hindarto (2019) sekitar ke-13 telah menyaksikan kemunculan beberapa Majapahit di Borneo, terdapat sebuah karya Prapanca iaitu Negara Kertagama ada menyebutkan terdapat beberapa buah tempat di bawah empayar Majapahit dianggap menyamai nama yang hamper menyerupai dengan beberapa tempat di Sarawak pada hari ini iaitu Sawaku, Melano dan Kalka (Mansor \& Pawi,2019). Perkara ini turut menyaksikan kemunculan sebuah kerajaan bercorak Hindu di utara Kalimantan Barat iaitu kerajaan Wijayapura atau kerajaan Sambas Kuno. Ibu kota Kerajaan Wijayapura 
dipercayai terletak di sekitar muara Sungai Rejang. (wilayah Sarawak kini). Beberapa artifak Hindu Buddha seperti gendang dongson, manik-manik batu dari India dan patung Boddhisatvas (patung emas Buddha) telah dijumpai lembah Sungai Sambas, Kalimantan Barat menunjukan telah wujud bentuk perdagangan sezaman atau lebih awal dari tamadun Sriwijaya (Nik Hassan Suhaimi Nik Abd Rahman, 1994). Kedudukan geografinya yang strategik iaitu terletak di utara Kalimantan Barat dan berhadapan dengan Laut China Selatan yang merupakan laluan pedagangan dari India dan China ke Borneo pada ketika itu. Melihat kepada jajaran wilayah kekuasaan Wijayapura sehingga ke Sungai Rejang yang menjadi penempatan terbesar masyarakat Iban di Sarawak, memberikan satu pendapat iaitu pada suatu masa dahulu, mungkin sesetengah masyarakat Iban tidak pernah bermigrasi dari Kalimantan, Indonesia namun merupakan penduduk asal yang terasimilasi dengan pelbagai bentuk corak keagamaan dan budaya Hindu Buddha di Sarawak.

Selain itu, berdasarkan Vida Pervaya (1998) telah mengemukakan satu fakta terhadap pengujian sampel arang candi yang ditemukan di Amuntai, Kalimantan Selatan pada tahun 1998. Beliau mengatakan telah wujud sebuah kerajaan yang lebih tua daripada kerajaan Kutai iaitu kerajaan Nan Sarunai yang berkisar di antara 242 sehingga 226 SM. Kewujudan Nan Sarunai jelas dinyatakan dalam tradisi lisan iaitu sebuah lagu Wadian yang diturunkan secara generasi ke generasi oleh Dayak Maanyan. Penceritaan dalam lagu tersebut menyatakan bahawa mereka sudah memiliki sebuah negara yang bernama Nan Sarunai (Muhammad Zaenal Arifin,1994). Kerajaan Nan Sarunai dipercayai telah didirikan oleh etnik Dayak Maanyan iaitu salah satu suku yang tertua di Kalimantan Tengah dan Selatan. Kerajaan ini dipercayai telah mengalami zaman kemunduran semasa permerintahan Raden Anyan apabila diserang oleh Kerajaan Majapahit pada tahun 1358 yang sedang giat melakukan perluasan kuasa di kepulauan Borneo. Peperangan tersebut disebut sebagai Usak Jawa yang merujuk kepada serangan orang Jawa. Walaubagaimanapun, status Nan Sarunai sebagai sebuah kerajaan pada era tersebut masih dalam perdebatan sehingga kini. Namun begitu, cadangan ini menyokong kepada kenyataan kajian Simonson yang mengatakan bahawa masyarakat Iban merupakan kelompok Dayak asal yang telah lama wujud di Pulau Borneo.

\section{Pembangunan budaya dan Sosial di Tembawai Tampun Juah}

Kemakmuran dan keharmonian yang baik di Tembawai Tampun Juah telah menyaksikan migrasi masyarakat Iban dari setiap penjuru Borneo untuk bergabung di Tampun Juah bagi mencari perlindungan dan kehidupan yang lebih baik. Perlahanlahan masyarakat Ibanik di Tembawai Tampun Juah telah membentuk budaya dan legasi yang beradaptasi daripada alam dan pengaruh budaya dari kerajaan awal seperti kerajaan Kutai dan Majapahit. Perkara ini dijelaskan oleh Abdul Rahman mengatakan bahawa pengaruh Hindu Buddha terhadap kepercayaan dan budaya masyarakat di Borneo adalah lebih awal iaitu lebih tahun kurang 800 Masehi terutamanya di bahagian barat Borneo yang menjadi laluan perdagangan dari India ke China (Abdul Rahman Haji Abdullah,1985). 
Walaubagaimanapun, menurut Vida Pervaya (2012) sebelum kemasukan pengaruh Hindu Buddha ke Borneo, masyarakat Dayak termasuklah masyarakat Iban telah memiliki sistem kepercayaan tradisional yang sendiri iaitu kepercayaan Kaharingan. Kaharigan yang membawa maksud hidup dan beranggapan bahawa agama ini telah ada selepas penciptaan alam. Masyarakat Dayak percaya kepada "Tuhan Tunggal" dan meyakini bahawa setiap alam semesta seperti gunung, bukit, sungai, angin dan tanah mempunyai semangatnya tersendiri. Agama ini dipercayai telah dianuti oleh masyarakat Dayak sejak era Kerajaan Nan Sarunai. Pada tahun 1387 Masehi selepas dikalahkan oleh Majapahit, agama Kaharingan telah berasimilasi dengan ajaran Siwa Buddha. Berdasarkan asimilasi tersebut telah mempengaruhi kepercayaan dan kebudayaan yang diwariskan oleh masyarakat Iban kini.

Dalam sistem kepercayaan lama (Pengarap Lama) masyarakat Iban, mereka mempercayai bahawa semua benda hidup dan benda bukan hidup mempunyai semangat seperti gunung, sungai dan pokok. Selain itu, mereka percaya wujudnya alam ghaib yang dinamakan Panggau Libau dan Gelung Batu Nakung iaitu tempat tinggal para dewa-dewi. Mereka percaya bahawa dewa-dewa Iban akan menjelma sebagai burung iaitu berdasarkan kepada tujuh jenis burung dalam kepercayaan Iban. (Jenis Burung: Ketupung, Bejampung, Pangkas, Embuas, Papau dan Nendak). Burung-burung ini mempengaruhi budaya Iban terutamanya dalam aspek adat dan pantang larang (Durin, 2014) Selain itu, masyarakat Iban percaya akan alam kematian Menua sebayan iaitu tempat roh nenek moyang yang telah meninggal dunia.

Pengaruh Hindu Buddha dapat diihat dengan jelas dalam sistem kepercayaan Iban, terutamanya dalam Adat Miringi iaitu sebuah ritual memberi makan kepada kuasa ghaib yang dipercayai mampu menolong dan mendengar permintaan mereka. Menurut Motey \& Tugang (2018) Adat Miring merupakan upacara berdoa dengan memberi persembahan makanan yang disimpan dalam piring (dulang). Persembahan tersebut adalah merupakan beberapa jenis bahan makanan seperti pulut, telur, bertih jagung, penganan (sejenis kuih tradisional), kapur, rokok dan air tuak (air beras yang ditapai). Selalunya, persembahan Adat Miring ini akan dilakukan mengikut nombor ganjil, bergantung dengan upacara yang hendak dilaksanakan. Tujuan upacara Miring ini diadakan adalah bagi memohon doa dan keberkatan daripada tuhan yang disebut sebagai Petara.

Pemberian atau persembahan makanan kepada kuasa ghaib telah diamalkan di dalam budaya Jawa yang menganut agama Hindu Buddha sejak tahun 387 Masihi. Sejarahnya bermula apabila Kepulauan Jawa dilanda wabak penyakit berjangkit sehingga mengorbankan ribuan penduduk di Pulau Jawa. Melihat keadaan ini, Sang Prabu memanggil seorang Brahaman untuk menyelesaikan bencana tersebut. Lalu, diceritakan bahawa Brahaman telah melakukan upacara sesaji Raja Weda (ritual persembahan makanan) dan telah memerintahkan seluruh rakyat untuk melakukanya setiap tahun. Budaya tersebut telah menjadi tradisi dan meresap kepada etnik lain di 
nusantara termasuklah masyarakat Iban (Setiawan,2015). Melalui amalan yang memiliki persamaan tersebut, jelas menunjukan bahawa kebudayaan masyarakat Iban kini adalah menerima pelbagai pengaruh daripada kebudayaaan sekitar Nusantara iaitu Hindhu Buddha dan telah diubahsuai berdasarkan kepada kesesuaian amalan hidup masyarakatnya.

Dalam sistem pemerintahan, Kerajaan Tembawai Tampun Juah memiliki sistem pentadbiran yang teratur dan sistematik. Sistem pemerintahan di Tembawai Tampun Juah diketuai oleh beberapa orang Temenggung (sehingga kini masih diamalkan oleh masyarakat Iban di Sarawak) yang mengawal selia pemerintahan di Tembawai Tampun Juah. Sistem ketemenggungan ini adalah merupakan salah satu faktor sistem pemerintahan tradisional di Nusantara berdasarkan konsep "Daulat dan Derhaka" serta penggunaan unsur-unsur mitos dan lagenda adalah merupakan amalan yang digunapakai oleh golongan pemerintah untuk menggembleng dan memobilisasikan sokongan rakyat terhadap kepimpinan mereka. Dalam konsep ini pelbagai unsur seperti animisme dan Hindu Buddha telah diterapkan dalam sistem pemerintahan tradisional Nusantara pada ketika itu (Abdul Rahman \& Musa, 2020). Sistem pemerintahan di Tembawai Tampun Juah adalah berdasarkan status sosial masyarakatnya seperti;

i. Bangsa Masuka atau Suka iaitu keturunan raja dan bangsawan (purih raja)

ii. Bangsa Meluar iaitu Rakyat Biasa

iii. Bangsa Melawang iaitu hamba yang berhutang dengan bangsa Masuka (ulun)

\section{Kejatuhan Kerajaan Tembawai Tampun Juah}

Kejatuhan Kerajaan Tembawai Tampun Juah dapat dilihat melalui dua perspektif iaitu berdasarkan kepada cerita lisan yang diturunkan generasi ke generasi oleh masyarakat Iban dan penelitian sejarah kerajaan awal di Kalimantan Barat sebelum kemasukan agama Islam. Informan Datuk Sri Edmmund Langgu mengatakan dalam tradisi lisan Iban, punca perpisahan masyarakat Iban dengan Urang Panggau adalah disebabkan oleh beberapa konflik kira-kira ratusan tahun yang lepas. Konflik yang paling dominan apabila masyarakat Iban dikehendaki untuk mematuhi adat berkabung iaitu Ngulit atas kematian Apai Keling yang bernama Gemuring Gading selama tiga tahun lamanya. Selama tempoh tersebut tidak dibenarkan semua makhluk yang hidup untuk membuat bunyi bising. Apabila terdengar bunyi ayam yang berkokok, ayam tersebut akan disembelih, begitu dengan binatang-binatang yang lain seperti anjing dan babi akan dibunuh sekiranya mengeluarkan bunyi yang bising. Kekejaman tersebut dilihat tidak berperikemanusiaan, sehinggakan bayi yang turut dibunuh sekiranya bunyi tangisannya didengari di seluruh rumah panjang.

Sehinggalah pada suatu hari, terjadilah banjir besar di Batang Kapuas yang menghasilkan bunyi yang bising akibat daripada deruan arus air yang mengalir telah menyebabkan Dewa Perang Bungai Nuing menjadi sangat marah dan baran. Beliau yang tidak senang mendengar deras air tersebut menghempas tebing bercadang untuk menyekat air Sungai Besar Kapuas agar tidak mendengar bunyi tersebut. Beliau yang 
nekad telah mendaki Bukit Semalawi, lalu dibelahnya bukit tersebut dan dialihnya ke Batang Kapuas untuk memberhentikan air sungai dari terus mengalir namun tidak berjaya kerana terjatuh semasa memikul bukit tersebut. Beliau yang tidak puas hati membawa perasaan marah yang teramat lalu balik semula ke rumah panjang. Semasa dalam perjalanan balik, beliau terdengar suara kanak-kanak Iban yang sedang riuh mandi- manda di sungai, bermain-main dengan melempar tanah. Semasa bermain, seorang budak telah menangis kuat kerana terkena tanah yang dilempar oleh rakannya. Dewa Bungai Nuing yang mendengar tangisan tersebut telah menengur dengan nada yang marah agar budak tersebut berhenti menangis, namun arahan tersebut tidak diendahkan oleh anak itu. Maka, beliau yang sangat marah lantas mengambil wi (sejenis rotan) dengan duri-durinya sekali lalu diiikatnya pada tubuh anak tersebut dan direndamnya di dalam lubuk yang disebut sebagai Lubok Ulak Jarah sehingga pengsan. Tindakan Dewa Bungai Nuing tersebut telah menyebabkan perasaan tidak puas hati masyarakat Iban yang lain sehingga mereka mengambilkan untuk berpindah lari dari Urang Panggau. Setengah daripada penduduk di rumah panjang telah berpindah mengikut Keling dan setengahnya lagi berpindah mengikut Buntak (belalang) ke Bukit Kedempai iaitu terletak di wilayah Sarawak (Nalong Buda \& Johnny Chuat, 2007).

Selain itu, menurut Lemambang Abang Entrey, perpisahan di antara masyarakat Iban dengan Urang Panggau adalah disebabkan oleh konflik di antara Keling dengan Sengalang Burung yang berebutkan azimat warisan keluarga di antara keluarga Keling dengan keluarga Sengalang Burung. Konflik tersebut berpunca apabila berebutkan harta warisan iaitu azimat sakti iaitu taring gigi tenggiling. Dewa Keling mengakui bahawa azimat yang dipegang oleh Sengalang Burung adalah harta pusaka yang diwariskan kepada bapanya, Germuring Gading. Walaubagaimanapun, Dewa Sengalang Burung menafikan perkara tersebut dan akhirnya membawa mereka berpecah dan membawa haluan masing-masing. Konflik tersebut telah membawa Keling dan pengikutnya pindah ke Panggau Libau manakala Sengalang Burung dan pengikutnya berpindah ke Langit Landong.

Faktor penolak yang membawa kepada perpisahan masyarakat Iban dengan Urang Panggau adalah disebabkan hukuman yang dilaksanakan kepada pasangan yang Kawin Mali. Kawin Mali adalah adalah merupakan perkahwian di antara kedua individu yang mempunyai hubungan kekeluargaan seperti adik- beradik, sepupu atau saudara-mara yang dekat. Dalam kepercayaan masyarakat Iban, hubungan tersebut dianggap tidak biasa dan taboo dalam budaya masyarakatnya, bahkan sehingga ke hari ini. Masyarakat Iban percaya bahawa perkahwinan yang memiliki hubungan kekeluargaan yang dekat akan mengakibatkan tanah dan tanaman tidak menjadi, wabak penyakit dan kematian akan menyerang seluruh rumah panjang. Oleh itu hukuman bunuh dengan merejam kedua-dua pasangan tersebut dengan buluh akan diberikan kepada pesalah, kemudian darahnya akan dihanyutkan di sungai bagi menyucikan semula tanah yang kotor. Selain itu, perkahwinan sedarah akan menjadikan genetik anak yang tidak normal dan membawa sial dalam keluarga. Anak 
yang dilahirkan melalui perkahwinan sedarah berisiko untuk menjadi cacat anggota badan atau tidak waras. Oleh itu, masyarakat Iban membantah adat hukuman tersebut dengan melarikan diri dari Urang Panggau. Kini, bagi masyarakat Iban yang masih menganuti agama lama nenek moyang mereka, hukum adat tersebut masih dikekalkan namun mengadaptasi dengan rasa yang lebih berperikemanusiaan iaitu dengan membuat ritual khusus dengan mengorbankan darah khinzir sebagai tanda keampunan kepada Petara dan roh nenek moyang.

Selepas konflik yang berlaku dengan manusia di Tembawai Tampun Juah. Dewa Keling dan pengikutnya mendaki Bukit Kedempai selama tiga hari tiga malam yang tingginya dikatakan hanyalah kurang sedepa daripada pengayuh sampan hendak menyentuh langit. Sebaik sahaja sampai ke puncak Bukit kedempai, Dewa Bungai Nuing lalu mencabut sepohon kayu yang besar untuk dijadika sebagai titian ke langit dan diikat menggunakan tali bagi mengukuhkan titian tersebut. Selepas semua pengikut Dewa Keling meniti titian tersebut, Dewa Bungai Nuing terus menarik semula titian kayu untuk mengelakan masyarakat Iban mengikuti mereka di kemudian hari, mereka yang masih tidak berpuas hati dengan perpisahan tersebut telah menjauhkan diri daripada masyarakat Iban. Oleh itu, penempatan mereka ini dikenali dengan nama Panggau Libau yang terletak di antara dunia dan langit. Manakala masyarakat Iban telah berpindah mengikut Buntak (belalang) ke kaki Bukit Kedempai iaitu terletak di wilayah Sarawak di bahagian Batang Lupar. Dari Batang Lupar tersebut masyarakat Iban mula berpecah sehingga membentuk kepada penempatan mereka kini di Sarawak. Menurut informan Jimbun Tawai, perpisahan yang terjadi dalam sejarah budaya Iban bukanlah kali pertama yang berlaku, sebelum ini mereka telah berpisah dengan Petara (tuhan) sebanyak lebih dari tiga kali, namun, perpisahan yang terakhir ini bersama Urang Panggau adalah merupakan perpisahan yang mutlak masyarakat Iban sebagai manusia dengan makhluk yang dipercayai mempunyai kuasa yang sakral.

Konflik yang terjadi tersebut telah menyebabkan berlakunya perpisahan di antara masyarakat Iban dan Urang Panggau. Perpisahan tersebut telah menyebabkan masyarakat Iban tidak lagi melihat kewujudan dewa-dewi yang dahulunya hidup bersama-sama dengan nenek moyang mereka di Tembawai Tampun Juah. Menurut informan Lemambang Bachaw Undan semasa berpisah dengan masyarakat Iban, Petara dan Urang Panggau telah meninggalkan beberapa tanda dan pesan kepada masyarakat Iban untuk kembali dan menetap semula di Tembawai Tampun Juah. Tanda-tanda yang ditinggalkan oleh Petara adalah merangkumi tinggalan objek budaya seperti patung berukir yang disebut Pentik, "Kayu tangga Tebelian" dan "Gerbang Pintu Kayu Tebelian". Selain itu, menurut informan Lemambang Kudi:

"Perpisahan tersebut telah membawa masyarakat Iban bermigrasi ke Batang Entungau di Merakai, Kalimantan. Migrasi tersebut menyaksikan pertemuan terakhir di antara masyarakat Iban dengan urang panggau buat selamanya. Akibat dari perpisahan tersebut telah menyebabkan masyarakat Iban hilang pedoman dan 
jati diri disebabkan kebergantungan mereka selama ini dengan Urang Panggau (orang ghaib atau kayangan) sebelum ini. Beliau turut mengatakan bahawa masyarakat Iban ketika itu, hidup dalam keadaan yang liar dan sentiasa bertelingkah antara satu sama lain. Faktor tersebut telah mengakibatkan masyarakat Iban menjadi lemah, tidak harmoni dan jahil dalam kehidupan mereka. Impak dari perpisahan tersebut telah mengakibatkan kemunduran dan penyisihan budaya Iban (undang-undang tradisional Iban, kemahiran tempatan dan adat Iban) yang diwariskan oleh urang panggau hilang dari budaya masyarakat Iban buat seketika"

(Temubual bersama Lemambang Kudi, 2020)

Menurut Lemambang Kudi berdasarkan cerita lisan dari Iban Skrang, Layar dan Batang Ai setelah beberapa ketika masyarakat Iban hidup dalam keadaan kacau bilau. Pada tahun 1750 mereka telah mengadakan satu aum (mesyuarat) untuk memilih Tuai Tuga Serang (ketua) bagi memimpin bangsa Iban yang lain dengan cara Begawai Kenunsung (upacara adat) di Sungai Pelasok, Batang Skrang. Tujuannya adalah untuk menghidupkan semula amalan Ngayau. Dikatakan hajat masyarakat Iban tersebut telah didengari oleh Petara dan Urang Panggau lalu mengangkat seorang pemuda Iban yang bernama Berdana, Ijau lelayang atau dikenali sebagai Temenggung Simpi untuk membimbing dan menyatukan semula masyarakat Iban dan hidup berteraskan kepada hukum dan adat yang telah diajarkan oleh Petara Sengalang Burong. Semasa diangkat oleh Urang Panggau menjadi Tuai Iban (ketua), Temenggung Simpi telah dihadiahkan objek budaya Iban iaitu sumpit, rajut (anyaman bakul), nyabor (parang), ukiran kenyalang, dan bendera. Artifak-artifak yang diberikan oleh urang panggau dipercayai mempunyai kuasa sakti dan mampu melindungi masyarakat Iban daripada di serang oleh bangsa lain. Selain itu, selama masyarakat Iban masih menyimpan artifak budaya tersebut mereka akan sentiasa menang dalam setiap ekspedisi ngayau.

Menurut informan Lemambang Ijau Buja kekuatan yang dimiliki oleh Temenggung Simpi adalah sangat hebat. Temenggung Simpi dipercayai dapat melakukan komunikasi dengan Petara dan Urang Panggau melalui ilmu batin dan mimpi. Petara telah berpesan melalui Temenggung Simpi kepada masyarakat Iban iaitu " $t i$ kita beguna ka kami, kita mesti begendang rayah, bepiring ading, bebunuh ka manuk, bepasuk ka ngepan Iban lalu nabur ke berau kuning. Ti kita nadai berpiring ading enda kami ulih datai". (Jikalau kamu (merujuk kepada orang Iban) ingin meminta pertolongan daripada Petara maka kamu haruslah bergendang, menyediakan persembahan makanan, mengkorbankan darah ayam, mengharuskan memakai pakaian tradisional Iban dan menaburkan beras kuning. Jikalau kamu tidak menyediakan keperluan diatas, maka kami di Panggau Libau tidak dapat datang untuk membantu). Pukulan Gendang Rayah (sejenis muzik Iban) adalah bagi tujuan untuk memberi perkhabaran kepada Urang Panggau untuk datang menjenguk ke dunia manusia. Bermula dari detik tersebut, masyarakat Iban telah menjadikan pesanan tersebut sebagai satu warisan dan diturunkan selama generasi ke generasi. 
Walau bagaimanapun, menurut Nalong \& Johnny (2016) mengatakan kekuasaan Temenggung Simpi hanya berkuasa di kawasan Batang Tawang iaitu merujuk kepada penempatan masyarakat Iban di Kalimantan, Barat. Faktor ini adalah disebabkan oleh James Brooke pada ketika itu telah menyekat kekuasaan Temenggung Simpi ke kawasan penempatan Iban di Sarawak. Bagi mengatasi kemaraan Temenggung Simpi ke Sarawak, maka James Brooke telah melantik Temenggung Koh dan Temenggung Jugah untuk menjadi ketua bagi masyarakat Iban di Batang Rejang (merujuk kepada daerah Kapit kini). Berdasarkan kepada legenda tersebut, jelas menunjukan bahawa masyarakat Iban tradisional adalah sangat dekat dengan alam ghaib yang dikenali sebagai Panggau Libau, tempat tinggal dewa-dewi Iban seperti dewa Keling dan dewi Kumang. Kepercayaan tersebut masih lagi menebal sehingga kini dalam amalan kehidupan mereka yang tinggal di rumah panjang walaupun rata-ratanya masyarakat Iban telah banyak menganut agama yang baharu iaitu agama Kristian dan agama Islam. Kepercayaan terhadap Petara dan Urang Panggau masih lagi disebut-sebut dan dikenang dalam setiap tindakan dan amalan kebudayaan mereka namun telah diubahsuai berdasarkan kepada tuntutan agama yang baharu.

\section{Kejatuhan Tembawai Tampun Juah dari Perspektif Sejarah}

Daripada perspektif sejarah, kemakmuran di Tembawai Tampun Juah telah menimbulkan rasa tidak senang Kerajaan Sukadana yang terletak di kabupaten Ketapang. Kerajaan Sukadana merupakan kerajaan yang dipindahkan dari Tanjungpura semasa era pemerintahan Majapahit di Borneo pada abad Ke-14 bagi mengelakan serangan lanun laut iaitu dipercayai masyarakat Iban (Sea Dayak) dan pelaut Iranun (Filipina) (Drake Allen Richard, 1995). Menurut Harianto Darmardi (2012) kewujudan kerajaan Tembawai Tampun Juah dilihat sebagai satu ancaman oleh Kerajaan Sukadana, kerana Tembawai Tampun Juah dikatakan makmur, kaya raya dan dibarisi oleh pahlwan-pahlawan Iban yang tidak takut mati apabila beperang. Oleh sebab itu kerajaan Sukadana telah melakukan beberapa ekspedisi perang untuk mengalahkan Tembawai Tampun Juah. Percubaan pertamanya adalah menghantar rombongan askarnya menyerang Tembawai Tampun Juah melalui jalan Laban Lawai dan seterusnya memasuki Sungai Kapuas sehingga ke hulunya. Walaupun pergerakan rombongan perang Sukadana ini dilakukan dalam keadaan yang senyap namun tanpa mereka sedari segala gerak-geri mereka telah diperhatikan dan dihidu oleh pahlawan Iban di Tembawai Tampun Juah yang memang sudah mengatur strategi untuk menyerang balas tentera Sukadana. Tatkala rombongan tentera Sukadana menghampiri kawasan Tembawai Tampun Juah, secara tiba-tiba mereka telah dikepung dengan serangan damak beracun yang disumpit oleh pahlawan Iban dari segenap sudut. Tentera Sukadana yang terkejut lantas bertaburan melarikan diri sebelum sempat menyerang kerajaan di Tembawai Tampun Juah. Kekalahan pertama itu, tidak mematahkan semangat kerajaan Sukadana yang dibawah perintah Mahajapahit malah mereka telah melakukan ekspedisi serangan yang kedua dengan menggunakan laluan yang lain iaitu dari Teluk Air menuju ke Tayan, Sanggau dan memasuki Sungai Sekayam bagi menuju ke hulu Tembawai Tampun Juah. 
Walaubagaimanapun, askar Sukadana tidak mampu menghakis serangan balas tentera Iban di Tembawai Tampun Juah yang sememangnya mahir dan tidak kelihatan semasa perang. Peristiwa perang tersebut diingati sebagai Perang Sumpit kerana senjata yang digunakan dalam peperangan adalah sumpit beracun.

Kerajaan Sukadana mengakui akan kehebatan dan kemahiran perang pahlawan Iban di Tembawai Tampun Juah. Oleh itu, dalam serangan ketiga mereka telah merancang untuk membuat serangan halus iaitu menggunakan ilmu hitam. Serangan ilmu hitam tersebut telah menyebabkan kekacauan di Tembawai Tampun Juah. Penduduk di Tembawai Tampun Juah terpaksa berhadapan dengan bau yang sangat busuk, ancaman serangan serangga berbisa seperti lipan dan kala jengking dan tanah Tembawai Tampun Juah yang subur menjadi kering kontang serta tidak mengeluarkan hasil tanaman seperti sedia kala. Bagi menyelesaikan masalah tersebut, ketua-ketua suku telah mengadakan satu perjumpaan penting yang disebut sebagai Pekat Banya. Hasil perbincangan tersebut telah mencapai kata sepakat untuk berpindah dari Tampun Juah mengikut ketemenggungan masing-masing. Sebelum berangkat mereka telah meninggalkan pesanan sesama sendiri "Jika suatu hari nanti, kita menemukan tempat yang subur, sejahtera dan damai maka kita akan berkumpul semula dan memulakan hidup baharu seperti di Tampun Juah" Proses migrasi tersebut dipecahkan kepada tiga kumpulan:

i. Kumpulan pertama yang meninggalkan Tembawai Tampun Juah adalah kelompok Dayak Batang Lupar (Iban) yang berangkat menyelusuri Sungai Sai, tembus ke muara Sungai Ketugau sehinggalah sampai ke Batang Lupar, Kapuas Hulu.Dari Batang Lupar, kelompok ini telah berpecah dan membentuk sub-sub kecil Ibanik iaitu Kantuk, Undup, Gaat, Saribas, Sebaruk dan Skrang telah menyebar di Sarawak mencari tanah baharu serta kehidupan baharu.

ii. Kelompok yang kedua adalah Dayak Ketugau. Mereka telah bergerak menyelusuri aliran Sungai Sai, terus masuk ke Sungai Ketugau dan menetap di sepanjang Sungai Ketugau lalu membentuk sub-sub kecil iaitu Ketugau, Bugau, Banyur dan Tabun.

iii. Kelompok yang terakhir adalah Dayak Mualang. Kelompok ini merupakan etnik yang terakhir bertahan di Tampun Juah kerana menurut cerita mereka sedang menunggu seorang wanita Mualang yang sarat mengandung untuk melahirkan anak. Walaubagaimanapun, disebabkan terlalu lama menunggu waktu untuk bergerak maka kelompok Mualang telah kehilangan jejak migrasi kelompok Iban dan Kelompok Ketugau. Oleh itu, mereka memilih untuk membuat perjalanan sendiri ke Tanah Tabo'.

\section{Perbincangan}

Menurut informan Datuk Sri Edmmund Langgu, kerajaan Iban yang gah dan kuat mungkin sudah tenggelam dalam lipatan sejarah, namun artifak Temengung Simpi yang dihadiahkan oleh Urang Panggau masih dijaga dan disimpan secara rapi dan rahsia. Menurut lagenda empat tempat yang dipercayai menjaga artifak Temengung 
Simpi adalah di Sadap, Sumpak, Serian, dan Tunggak. Selain itu, bagi memperingati semula masa puncak kejayaan masyarakat Iban di Tembawai Tampun Juah terdahulu, masyarakat Iban dari Sarawak, Indonesia, Brunei dan Sabah telah mendirikan Sandung Kenyalang. Sandung Kenyalang (tiang kenyalang) adalah sebagai lambang kegemilangan dan kemegahan dalam kebudayaan Iban. Pada masa dahulu, apabila pahlawan-pahlawan Iban berhasrat untuk melakukan ekspedisi Ngayau, maka tiang kenyalang akan didirikan dengan mengadakan upacara Gawai Kenyalang selama tujuh hari tujuh malam. Tujuannya adalah sebagai lambang keberanian dan kekuasaan mereka di atas tanah Borneo.

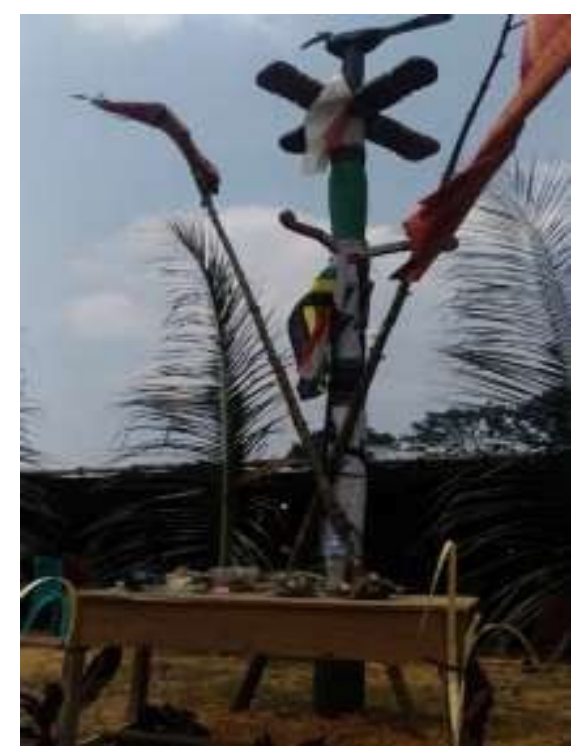

Rajah 4: Sandung Kenyalang (Sumber: Suara Sarawak, 2019)

Semasa masyarakat Iban tradisional masih mengamalkan budaya Ngayau, tiang kenyalang akan didirikan terlebih dahulu bagi memohon keampunan dosa kepada petara bagi memohon restu dan kejayaan dalam medan perang untuk mengumpulkan kepala musuh. Menurut informan Jimbun Tawai, apabila masyarakat Iban dahulu kembali dari ekspedisi Ngayau, maka Gawai Kenyalang harus diadakan dengan segera bagi menyambut antu pala (kepala musuh) untuk dibawa masuk ke rumah panjang bagi mengakui dan memohon keampunan dari Petara untuk menghilangkan perasaan bersalah selepas melakukan ekspedisi Ngayau. Jikalau, individu tersebut melengahkan untuk mengadakan Gawai Kenyalang maka risiko untuk mati atau menjadi gila adalah sebagai bayarannya. Kini tradisi tersebut telah berubah seiring dengan perubahan waktu, perayaan Gawai disambut bagi meraikan berakhirnya musim menuai padi dan menziarahi saudara mara bagi mengeratkan silaturahim. Setiap tahun, daerah Sanggau, Kalimantan Barat sentiasa dibanjiri dengan kedatangan masyarakat Iban dari seluruh pelusuk Borneo iaitu Sabah, Sarawak, Kalimantan dan Brunei bagi melakukan upacara ritual khas untuk mengenang semula zaman kegemilangan Tembawai Tampun Juah suatu ketika dahulu terutamanya ketika musim perayaan Gawai Dayak serta memperingati tanah leluhur mereka. 


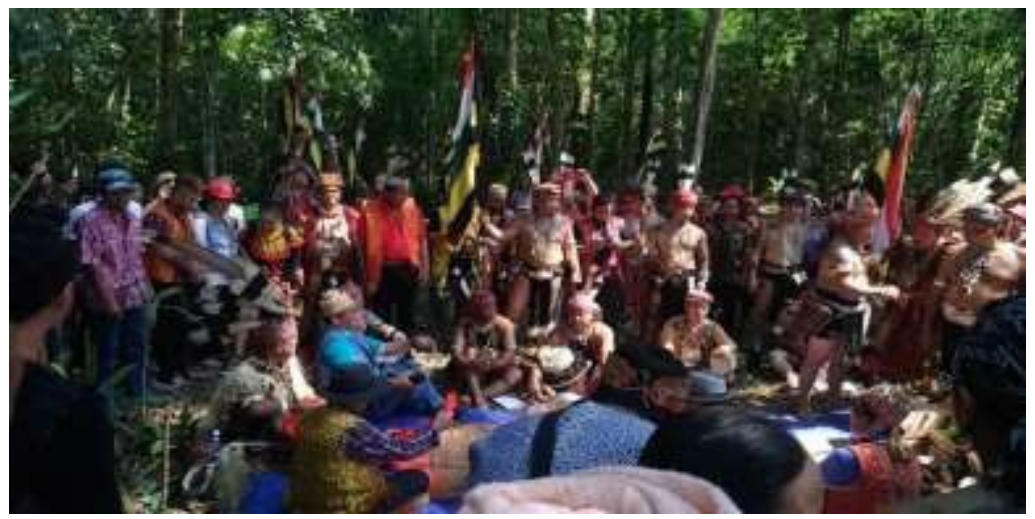

Rajah 5: Sambutan Gawai di Tembawai Tampun Juah (Sumber: Suara Sarawak, 2019)

Bagi mengekalkan nilai tradisi dan sejarah Tembawai Tampun Juah, sebuah persatuan Iban iaitu SADIA (Sarawak Dayak Iban Association) Sarawak telah merancang beberapa pelan pembangunan di Tampun Juah berdasarkan konsultansi Datuk Sri Edmmund Langgu mengenai hala tuju di Tembawai Tampun Juah pada masa akan datang. Beberapa cadangan yang telah diusulkan oleh Datuk Sri Edmmund Langgu bagi memelihara dan memulihara tapak sejarah Tampun Juah adalah (i) mendaftarkan kawasan Tampun Juah sebagai tapak warisan budaya dengan kerajaan Indonesia,(ii) membina bangunan ikonik sebagai mercu tanda budaya Dayak di Tampun Juah, (iii) mengisyiharkan agar sambutan Gawai Dayak setiap tahun perlu diraikan di Tampun Juah dan (iv) membangunkan tugu peringatan sejarah sebagai lambang dan tanda ketamaduan gemilang masyarakat Dayak terdahulu yang pernah wujud di Tampun Juah. Bahkan Kerajaan Indonesia telah memerintahkan larangan untuk menjarah, menebang atau membuka ladang di tanah adat Tampun Juah dan merizabkan hutan di Tembawai Tampun Juah sebagai hutan simpan kerajaan Indonesia.

Kewujudan Tembawai Tampun Juah berupaya untuk menjadi hub budaya dua negara dalam merapatkan silaturahim agar terus utuh di masa hadapan. Bahkan, masyarakat Iban, di Sarawak sentiasa menganggap masyarakat Iban di Kalimantan Barat sebagai saudara dan sering mengundang mereka ke Sarawak untuk menghadiri perayaanperayaan yang melibatkan budaya masyarakat Iban. Selain itu, Tembawai Tampun Juah juga turut memiliki kawasan hutan yang berkeluasan 651 hektar,dimana hasilnya kaya dengan kepelbagaian spesis flora dan fauna yang jarang dijumpai diluar kawasan Borneo, khususnya spesis burung Enggang atau nama sainstifiknya Buceros Rhinoceros.Kerajaan Malaysia dan Indonesia harus memikirkan satu langkah yang progresif untuk menampung kemampuan hutan Tembawai Tampun Juah yang dirasakan sesuai menjadi medan penyelidikan ilmu sainstifik berkaitan dengan kelestarian warisan semulajadi Borneo serta mempelajari kemahiran tradisi penduduk setempat dalam menjaga hutan rimba Borneo. Di samping itu, penjagaan hutan dari kedua- dua negara ini mampu membendung kebakaran hutan yang menyebabkan masalah jerebu dan menjadi isu berbangkit di antara Malaysia dan Indonesia di masa akan datang. 


\section{Kesimpulan}

Bagi generasi Iban baharu kini, nama Tembawai Tampun Juah mungkin terlalu asing dan mereka bahkan tidak pernah mengetahui akan kewujudannya. Namun melalui sumber-sumber lisan masyarakat Iban, mereka percaya Tembawai Tampun Juah adalah tanah leluhur mereka sebelum masyarakat Iban kini menyebarluas ke Sarawak sehingga ke Sabah (Merotai, Tawau) dan Semenanjung Malaysia (Johor dan Selangor). Melalui penyelidikan ini, diharap dapat membantu dalam melestarikan sumber lisan tradisional masyarakat Iban, agar tidak pupus ditelan zaman dan berfungsi sebagai penyelidikan rintis di masa hadapan.

\section{Rujukan}

Abdul Rahman Haji Abdullah. (1985). Asia Tenggara tradisional. Kuala Lumpur: Teks Publishing.

Abdul Rahman, M., \& Musa, M. (2020). Pengukuhan Kedaulatan Dinasti Temenggung Dalam Kesultanan Melayu Johor 1855- 1895.SEJARAH: Journal of The Department of History, 29(1), 1-17.

Alloy Sujarni (2008). Mozaik Dayak: Keberagaman Sub-Suku dan Bahasa Dayak di Kalimantan Barat. Pontianak: Institut Dayakologi.

Asmah Omar (1985) Susur Galur Bahasa Melayu. Kuala Lumpur: Dewan Bahasa dan Pustaka.

Beginda, Philip \& Bilcher Bala. (2018). "Pengaruh Demografi terhadap Perubahan SosioPolitik Orang Iban di Sarawak" SUSURGALUR: Jurnal Kajian Sejarah \& Pendidikan Sejarah, 6(1), 43-60.

Benedict Sandin (1962). Tiga Belas Bengkah Mimpi Tuai Dayak Iban. Kuching: Borneo Literature Bureau.

Bilon, Bibiana Motey \& Tugang, Noria (2018) The Iban Traditional Religion: Miring. Journal of Borneo -Kalimantan. Vol.4 (1), 38-42.

Buda, Nalong \& Chuat, Johnny. (2016) Iban Pegai Rajah Brooke (Edisi II). Kuching: Pegari Iban Production.

Drake Allen Richard (1995) Waktu dan Keterpisahan: Suatu Metanarrative Sejarah Lisan Mualang. Kalimantan Review, (3), 11-20.

Durin, Anna. (2014) Tikar Bemban.Kota Samarahan: Universiti Malaysia Sarawak. Hamid Darmadi (2017) Kerajaan Sukadana:Lagenda Masyarakat Sukadana, Kalimantan Barat. Kalimantan Barat: Balai Bahasa Provinsi Kalimantan Barat.

Harianto (2012) Kerajaan Sukadana:Lagenda Masyarakat Sukadana,Kalimantan Barat. Kalimantan Barat: Balai Bahasa Provinsi.

Hindarto, I. (2019). Analisis Struktural Pada Mukhalingga di Nanga Sepauk, Kabupaten Sintang, Kalimantan Barat (Structural Analysis of Mukhalingga In Sepauk, Kabupaten Sintang, West Kalimantan). Naditira Widya, 13(1), 1-12.

Ismail, E., \& Mohd Noor, A. (2019). Perkembangan Sektor Pertanian Di Sarawak, 1970-1981. SEJARAH: Journal of The Department of History, 28(2), 120-139. J.U. Lontaan. (1975) Sejarah, Hukum Adat dan adat Istiadat Kalimantan 
Barat.Kalimantan Barat: Pemda Tingkat I.

Kedit, Peter M (1993) Iban Bejalai. Malaysia: Ampang Press Sdn Bhd.

Kiyai, G. (2021). Sejarah Budaya Ngayau Dalam Masyarakat Iban di Sarawak: Ngayau Culture in the Iban Community in Sarawak. Jurnal Borneo Arkhailogia (Heritage, Archaeology and History), 6(1), 121-137.

Kiyai, G., \& Tugang, N. (2020). Artifak Budaya Masyarakat Iban: Warisan Dan Pusaka: Cultural Artefacts of The Iban: Heritage and Heirloom. Jurnal Kinabalu, 59-59.

Koentjaraningrat (1987) Manusia dan Kebudayaan di Indonesia. Jakarta: Penerbit Djambatan.

Kusmartono, Vida Pervaya Rusianti \& HarryWidianto (1997/1998) "Ekskavasi Situs

Candi Agung Kabupaten Hulu Sungai Utara Kalimantan Selatan". Berita Penelitian Arkeologi Balai Arkeologi Banjarmasin (2), 1-26

Kusmartono, Vida Pervaya Rusianti. (2012). Cultural Development: The Archaeology of Kalimantan Tengah and Kalimantan Selatan. Naditira Widya.Vol.6 (2), 153-169.

Mead,G.H.(1929) 'The Nature of the Past', in J.Coss (ed.), Essays in honor of John Dewey .New York: Henry Holt.

Mansor, S., \& Pawi, A. A. A. (2019). Peradaban Melayu Sarawak dalam Konteks Nusantara. Jurnal Melayu Sedunia, 2(1),278- 305.

Muhammad Zaenal Arifin. (1994). Struktur Birokrasi dan Srikulasi Elit di Kerajaan Banjar pada Abad XIX. (Tesis tidak diterbitkan) Yogyakarta. Universitas Gajah Mada.hlm.50.

Neilson Ilan Mersat. (2012) Sejarah Awal Migrasi Masyarakat Iban. Majlis Polemik

Sejarah Malaysia Sesi Ke-27, Kuching: Arkib Negeri Sarawak pada 19 September 2012.

Nik Hassan Suhaimi Nik Abd Rahman. (1994). A Commentary on the Relationship Between Penisular Malaysia dan Yunnan During the Prehistoric Era. Jurnal Arkeologi Malaysia.Vol.7 (1), 59-63.

Olick, J. (1999). Collective Memory: The Two Cultures. Sociological Theory, 17(3),

333-348. Retrieved June 15, 2020, from www.jstor.org/stable/370189

Peter Bellwood (2004) The Orgins and Dispersals of Agricultural Communities in Southeast Asia. London: UCL Press.

Pringle, Robert. (1936). Rajah and Rebel: The Ibans of Sarawak under Brooke Rule, 1841- 1941. Selangor: Nightingale Printing Sdn Bhd.

Sarip, M. (2020). Kajian Etimologis Kerajaan (Kutai) Martapura di Muara Kaman, Kalimantan Timur. Yupa: Historical Studies Journal, 4(2), 50-61.

Said, S. (2012) Sejarah Awal Kepulauan Melayu: Lima Buah Negeri Warisan Sarawak yang Hilang. CREAM -Current Researchin Malaysia. Vol,1 (1), 21-50.

Sarawak Population (2010) The Offical Portal of Sarawak Government.

Setiawan, Restu Budi. (2015) Bentuk, Makna, Dan Fungsi, Sesaji Mahesa Lawung

Dalam Tradisi Ritual Di Keraton Surakarta Hadiningrat, Tesis (tidak diterbitkan). Semarang, Universitas Negeri Semarang.

Simonson TS, Xing J, Barrett R, Jerah E, Loa P, Zhang Y. (2011) Ancestry of the 
Iban Is Predominantly Southeast Asian: Genetic Evidence from Autosomal, Mitochondrial, and Y Chromosomes. PLoS ONE 6(1), 1-8.

Siyok, Damianus \& Yankris. (2014). Discovery Manusia Dayak: Dari Peradaban Leluhur menuju Pertemuan Tumbung Anoi 1894 dan Kisah Manusia Dayak Masa Kini. Palangka Raya: Sinar Bagawan Khatulistiwa.

Sofwan Noerwidi. (2010). Beberapa Hasil Penelitian Kutai Mulawarman 2008: Situs Muara Kaman Dalam Perspektif Kawasan. Naditira Widya,Balai Arkeologi Banjarmasin, 4 (2), 160-170.

Stephen Oppenheimer (1998) Eden in the East: The Drowned of Southeast Asia. London: Weidenfeld and Nicolson.

Tahir, A., \& Mohd Noor, A. (2017). Visual Operasi Menghapus Serangan Lanun di Nusantara Dari Laporan The Illustrated London News, 1845-1872. SEJARAH: Journal of The Department of History, 22(2), 36-54.

\section{Informan}

Agus Mulyana (2019) Institut Dayakologi, Pontianak, Indonesia dalam seminar Gawai Serumpun Tampun Juah di Kalimantan Barat, Indonesia pada 5-8 September 2019.

Datuk Sri Edmmund Langgu ak Saga,Tokoh Politik dan Pakar Budaya Iban di Kuching pada ,10 Julai 2019.

Janet Rata Noel (50 tahun), Kurator Tun Jugah Foundation di Bangunan Tun Jugah, Kuching pada 11 April 2019.

Jimbun Tawai (65 tahun) Penyelidik Majlis Adat Istiadat Sarawak di Bangunan MAIS, Kota Samarahan pada 11 April 2019.

Lemambang (pendeta) Abang Enterey (85 tahun) di Rumah Ribun, Tinting Melaban, Sungai Kelampai, Saratok pada 10 September 2019.

Lemambang (pendeta) Kudi (75 tahun) berasal dari Rh.Assan Semena, Nanga

Medamit, Limbang pada pukul 12.30 pm, bertarikh 4 Mei 2019.

Lemambang (pendeta) Buchaw Undan (90 tahun) di Tinjar, Miri pada 4 Febuari 2019. Tugang Rima (76 tahun) di Rumah Kunjang, Entawa Asal, Sri Aman pada,11 Ogos 2019. 